\title{
Correlation and Causality between Inflation and Selected Macroeconomic Variables: Empirical Evidence from Pakistan (1990-2012)
}

\author{
Mehwish Nawaz, Muhammad Naeem, Sami Ullah, Salim Ullah Khan \\ Department of Economics, University of Peshawar, Peshawar, Pakistan \\ Email: Sami00212@yahoo.com
}

How to cite this paper: Nawaz, M., Naeem, M., Ullah, S. and Khan, S.U. (2017) Correlation and Causality between Inflation and Selected Macroeconomic Variables: Empirical Evidence from Pakistan (1990-2012). iBusiness, 9, 149-166.

https://doi.org/10.4236/ib.2017.94011

Received: November 2, 2017

Accepted: December 19, 2017

Published: December 22, 2017

Copyright (C) 2017 by authors and Scientific Research Publishing Inc. This work is licensed under the Creative Commons Attribution International License (CC BY 4.0).

http://creativecommons.org/licenses/by/4.0/

\begin{abstract}
Inflation is regarded as one of the most chronic problems in Pakistan and the recent surge of inflation (10.8) in consumer price index is a matter of serious concern in the economy [1]. Inflation imposes high cost on economies and societies; disproportionately hurts the poor and fixed income groups, creates uncertainty throughout the economy and undermines macroeconomic stability. It also results in inefficient resource allocation and hence reduces potential economic growth. High inflation has always penalized the poor. Lowering inflation therefore, directly benefits the low and fixed income groups. The present study focuses to examine the impact of various macroeconomic variables on inflation in Pakistan and to find their correlation and causal relationship with economic and econometric criterion by using time series data over the period of 1990 to 2012. To achieve this objective, regression analysis, correlation coefficient and granger causality test are used. Results from regression analysis indicate that money supply, government expenditure, government revenue, foreign direct investment and gross domestic product have positive impact on inflation in Pakistan, while interest rate shows negative impact. Correlation analysis confirms that there exists a positive association of inflation with money supply, government revenue, interest rate, foreign direct investment, gross domestic product, exchange rate and trade openness. The findings of the study also reveal that money supply as well as balance of trade granger causes inflation in the selected time period. I recommend that monetary and fiscal measures should be wisely coordinated in order to control the consistent increase in prices. The government should curtail expenditure and reduce money supply. Similarly, domestic production should be encouraged and trade deficit should be narrowed by increasing exports in the country.
\end{abstract}

\section{Keywords}

Inflation, Correlation, Deficit, Macroeconomic, Variables, Pakistan 


\section{Introduction}

Stability of general price level is one of the key concerns of policy makers and any abrupt changes in it have always posed a serious threat for economic growth of any economy. Maintaining a fair general price level has always proved to be a greater challenge in Pakistan throughout its history of economic growth. Unnecessary and abnormal increase in the general price level of goods and services reflects important repercussions for the economy. This elusive factor is called inflation and is defined as a continuous and persistent rise in the general price level in an economy whereas a percentage increase in the average level of prices over a year is called inflation rate [2].

Inflation is defined as the rise in prices of goods and services over time. It is the most difficult and highly sensitive issue that policy makers and governments face. It affects almost everyone in an economy. It erodes the value of currency by reducing its purchasing power which means that a rupee can purchase fewer goods today than it did previously [3].

Inflation is the key factor in determining public opinion about the performance of government. An inflation rate considered high or unacceptable may shift the public opinion away from government. This shift in public opinion may prove detrimental to government. Therefore, governments always adopt policy measures to address the evils of inflation effectively [4]. Throughout the history of Pakistan, inflation has become one of the serious problems. By examining the trend of inflation, from the time period 1973 to 1980 , it is observed that inflation rate was almost high at an average of around 14.3\%. In 1980s, the rate of inflation rose moderately at an average of $7.2 \%$ per year [1]. But again in 1990s, the rate of inflation rose to an average of $10 \%$ per year which created a severe disturbance. Comparatively, during 1990s, the economy was facing a vast period of inconsistent policies, liberalization, nuclear explosion and sudden changes in the government from time to time, which ultimately lead to a rise in inflation rate at an average of about $10 \%$ per year [1]. Similarly, expansion in the wheat procurement prices, borrowing by the government and the private sector, depreciation in the value of currency and further adaptations in expectations were the primary factors which caused an abrupt increase in the rate of inflation [5].

Inflation is still in double digits in Pakistan at a rate $10.8 \%$ from the month of July to April, and during the fiscal year 2011-2012, inflation rate is $13.8 \%$ in the last year whereas in April 2011, consumer price index was recorded to be $13 \%$. In September 2012 the rate of inflation is observed to be $8.79 \%$ while in fiscal year 2011-2012, food inflation is estimated to be $11.1 \%$ whereas non-food inflation is $10.7 \%$ comparable with $18.8 \%$ and $10.8 \%$ in the same period of 2012 [6].

It has been observed that the major factors causing a rise in the non-food prices are increase in electricity, gas, energy and fuel prices. From July to April 2011-2012, core inflation is recorded to be $10.4 \%$ in Pakistan. During July-April 2011-2012, Wholesale Price Index (WPI) is found to be $11.2 \%$ per annum as compared to $21.0 \%$ during last year. On the other hand, during the same time period 
of 2011 to 2012, Sensitive Price Indicator (SPI) is recorded at a rate of $8.5 \%$ as compared to $18.1 \%$ in the last year. The reason behind this sudden rise in overall inflation is a rapid increase in commodity prices, fuel prices and disruption in the aggregate supply that resulted from the massive floods adversely affecting the economy [6].

\section{Objectives of the Study}

The main objectives of this study are:

1) To investigate the various macroeconomic determinants of inflation in $\mathrm{Pa}$ kistan from 1990 to 2012.

2) To find out the existence of any causal relationship between the selected macroeconomic variables and inflation in Pakistan.

3) To study what impact does inflation has on balance of trade in Pakistan from 1990 to 2012 .

\section{Literature Review}

Lim [7] studied Tanzanian economy by investigating inflation and its determinants. Their analysis was based on a period 1992-1998. They concluded a positive significant relationship of inflation with exchange rate and money supply, while gross domestic product (GDP) was found to have an indirect relationship with inflation.

Alfaro [8] explored panel data from 1973 to 1998 in both the developing and developed economies and using short run analysis, he observed that inflation was not effected significantly by trade openness whereas exchange rate significantly affected inflation in the short run.

Khan [4] examined the impact of money supply on inflation in Pakistan by applying co-integration technique on quarterly data from 1975(1)-2003(IV). The study supported the concept of quantity theory of money and insisted that in short run, money supply had a great role in determining the level of inflation in a country. In the same way Saleem [9] supported that money supply growth and inflation were strongly correlated with each other because in Pakistan, money supply was the major determinant that contributed to a high level of inflation in the same time period.

Shahadudheen [10] used time series data for determining the level of inflation in Pakistan for the period 1993-2004, by using autoregressive integrated moving average (ARIMA) technique. The main focus in the study was to forecast inflation on short term basis. The variable used in the study was consumer price index.

Akbari [11] identified the major factors that determined the price level in $\mathrm{Pa}$ kistan from 1984 to 2004 and suggested that basically general price level was highly affected by money supply, foreign import prices and domestic level of output in the economy.

Abdullah [12] examined the economy of Saudi Arabia by investigating causal 
relation between money supply, government spending and economic growth in the country. The findings showed bilateral causal relationship between the three mentioned variables.

Khan [13] examined the economy of Pakistan by using time series data from 1972-2005. Their study examined inflationary trends in Pakistan using different econometric techniques for estimation of impact of different macroeconomic variables on inflation in Pakistan. They configured a positive impact of government and private borrowing, real-demand, price of imports, exchange rate, government revenues (taxes) and consumer price index lagged year with inflation.

Abdullah [12] studied Pakistan economy by analyzing the main constituents of food inflation by using Johansen co-integration technique. They analyzed a time series of 1972-2008 and observed that money supply, GDP per capita, food exports and imports and agriculture support prices were positively correlated with food inflation.

Mukhtar [14] examined the main factors that play a key role in determining the level of inflation in Iran for the period 1971-2006. For discovering the long run estimates in the model, the method of autoregressive and distributed lag model were used. The results were found that money supply, GDP, exchange rate, domestic and foreign prices were the major factors that contributed towards the domestic level of prices in the country.

Shahadudheen [10] focused on the prevailing circumstances that induced inflation in Pakistan by using vector autoregressive model and selecting the variables as consumer price index, money supply, gross domestic product, interest rate and output gap. Their results suggested that nominal rate of interest can be used as a key variable in controlling the level of inflation in Pakistan.

Kuijs [15] focused on the determinants of inflation in Pakistan using different price indicators i.e. consumer price index, wholesale price index, sensitive price index and GDP Deflator by using time series data from 1971 to 2005 for the analysis. Ordinary least square method had been employed for the estimation of values of coefficients. The explanatory variables that are budget deficit, exchange rate, wheat support price, level of imports, money supply, support price of sugarcane and cotton were found to have a direct effect on all the price indicators, while interest rate was indirectly related to all the explained variables in Pakis$\tan$.

Lim [7] critically analyzed the dynamic and simultaneous inter relationship between inflation and its determinants in Nigeria. Johansen co-integration technique and error correction model were used to analyze the determinants of inflation for the time series data for the period from 1970 to 2007 . The findings revealed that growth rate of $G D P$, money supply, imports, 1st lag of inflation and interest rate gave positive impression on inflation rate whereas other explanatory variables such as fiscal deficit and exchange rate were indirectly associated to inflation.

Ozlen [16] analyzed Nigerian economy by using time series data and Johansen co-integration method in the analysis. The study resulted a negative association 
of inflation with variables taken in the preceding year such as imports, $C P I$, exchange rate and government spending. On the contrary, inflation had a negative association with interest rate, level of exports, agriculture produce and crude oil exports taken in the preceding year.

Bashir [17] investigated the determinants of inflation in Pakistan using Johansen co-integration approach for the data period 1972-2010. The study investigated the demand side and supply side determinants of inflation and causal relationship among some macroeconomic variables in Pakistan. Study found that money supply, gross domestic product, imports and government expenditures are positively affecting consumer price index.

Solomon [18] examined inflation in India using time series data for a quarter time period of fifty four observations and for investigating the long run association between the inflation and its determinants, he adopted Johansen co-integration technique. The result analysis showed that money supply and gross domestic product was positively related to inflation whereas exchange rate and interest rate was negatively related to inflation in the long run.

Pakistan Economic Survey [19] conducted research to find out the effects of selected macroeconomic variables including inflation rate, exchange rate, interest rate, current account deficit and unemployment rate on stock returns of 45 companies from 11 different sectors in BIST by using Autoregressive distributed lag method (ARDL) research to identify. Their test results indicate that exchange rate and interest rate are the most significant factors in the stock price fluctuations of the companies.

Zîna [20] conducted a study in Romania to examine the impacts of Monetary Policy, Inflation and the Causal Relation between the Inflation Rate and Some of the Macroeconomic Variables. The results emphasize a significant direct relation between monetary policy, interest rate and inflation, which make interest rate an efficient instrument for central bank to prevent inflation. An inverse statistically significant relation between the inflation rate and the unemployment rate was found out. The result indicates that the inflation rate is an effective instrument in preventing the increase in unemployment.

Mosayeb [21] conducted a study to examine the role of inflation and unemployment on economic growth from 1996 to 2012 by using Autoregressive Distributed Lag (ARDL) Model. Microsoft version 4.0 and Eviews version 6.0 were used for model estimation. Model estimation results showed the significant and negative effect of inflation and unemployment on economic growth in long term, which indicated that inflation and unemployment decreased economic growth in long term. This issue revealed that authorities should diligently endeavor and plan to reduce and control inflation and unemployment.

\section{Research Methodology}

\subsection{Data and Data Collection}

The study which is an insight into Pakistan finds out the relationship of inflation 
with macroeconomic variables and causality among them takes into account annual time series data for the period 1990-2012. Data collected is of secondary nature and has been acquired from different national and international sources such as various Economic Survey of Pakistan, Annual Reports of State Bank of Pakistan, World Bank Development Indicators, and International Monetary Fund (IMF) and academic journals.

\subsection{Descriptive Statistics Technique}

To have some knowledge about the temporal and sequential characteristics of the variables taken and to properly compare and contrast them, descriptive statistics techniques have been followed in this study. Such techniques help properly identify and assess the physical characteristics of the data sets taken and tell us about their certain important features and characteristic such as means, standard deviations, skewness, kurtosis, and the upper and the lower points for each variable. Such results provide us with summary of the variables and data collected and thereby help us understand and interpret each data set in its first place by readily conveying some present and future aspects of them.

\subsection{Inferential Statistics Technique}

Inferential statistics techniques are helpful in verifying the inferences made and compare them with actual economic theory and thus enables to understand its footings in real world. Such techniques are used to test hypothesis and drawing some logical inferences or conclusions. In simple words, it is the way of putting economic theory in empirical tests and to check the findings whether they are consistent with real world or not. In this study, regression analysis has been done to empirically verify the relationship proposed by economic theory that exists between inflation and some macroeconomic variables. Inferential techniques allow us to test the hypothesis at certain confidence level; this study has taken $5 \%$ level of significance to test the hypotheses. Such techniques further tell us about certain important characteristics of the models analyzed which are explained in the proceeding chapter.

\subsection{Stationarity Checks}

Most macroeconomic time series data is regularly thought to be non-stationary and subsequently it is important to perform a pretest to guarantee if they are stationary or not in order to evade the issue of spurious results. Stationarity of a data series is a prerequisite for drawing meaningful inferences in a time series analysis. Generally a data series is called stationary series if its mean and variance are constant over a given period of time and the covariance between the two time periods does not depend on the actual time at which it is computed but it depends only on lag amid the two time periods. The correlation between a series and its lagged values are assumed to depend only on the length of the lag and not when the series started. This property is known as Stationarity and any 
series obeying this is called a stationary time series. The Stationarity of the time series has been verified by applying Augmented Dickey Fuller test (ADF) proposed by Dickey and Fuller $(1979,1981)$ to test if the time series variables are stationary.

The ADF test involves the estimation of one of the following three equations:

$$
\begin{gathered}
\Delta y t=\beta y t-1+\sum \delta i \Delta y t-i+\varepsilon t \\
\Delta y t=\alpha o+\beta y t-1+\sum \delta i \Delta y t-i+\varepsilon t \\
\Delta y t=\alpha o+\alpha 1 t+\beta y t-1+\sum \delta i \Delta y t-i+\varepsilon t
\end{gathered}
$$

where $\varepsilon t$ is white noise with zero mean and constant variance. The null hypothesis is that the variable $y t$ is a non-stationary series $(H 0: \beta=0)$ and is rejected when $\beta$ is significantly negative ( $H a$ : $\beta<0$ ). If the calculated $\mathrm{ADF}$ statistic is higher than McKinnon's critical values, then the null hypothesis $(H 0)$ is rejected and the series is stationary. Alternatively, non-rejection of the null hypothesis implies non-stationarity leading to the conduct of the test on the difference of the series until stationarity is reached and the null hypothesis is rejected.

\subsection{Model Specification}

Two different econometric models have been used to accomplish the objectives of the present study. Solomon [18] constructed four variables single equation model where inflation was regressed with three repressors namely budget deficit, gross domestic product, and exchange rate. They were followed by Olatunji [22] in his study. The first regression equation is constructed from the following functional form.

$$
C P I=f(M S, G E, G R, I N T, F D I, G D P)
$$

where,

$C P I=$ Consumer Price Index (or Inflation), which is the annual percentage change in the value of a fixed basket of goods and services with base year 2005.

$M S=$ Money Supply (Money and Quasi Money, M2).

$G E=$ Government Expenditures (Billion Rs.).

$G R=$ Government Revenues (Billion Rs.).

$I N T=$ Interest Rate (\%).

$F D I=$ Foreign Direct Investment (net inflows, Billion Rs.).

$G D P=$ Gross Domestic Product (Billion Rs.).

Since Exchange Rate $(E X R)$ and Trade Openness $(T O P)$ are also expected to affect Balance of Trade $(B O T)$ along with Inflation $(I N F)$, the second regression equation is derived from the following form.

$$
B O T=f(I N F, E X R, T O P)
$$

where,

$$
\begin{aligned}
& B O T=\text { Balance of Trade of Goods and Services. } \\
& E X R=\text { Official Exchange Rate. } \\
& T O P=\text { Trade Openness which is measured as }[\text { (Exports + Imports }) \div G D P] .
\end{aligned}
$$


The study also attempts to draw the correlation and causality inferences to find out the relation between the dependent and independent variables and to show the existence of any bidirectional or unidirectional relationships among the variables. To investigate any causality in between the selected variables, Granger causality test is employed.

\section{Results and Discussion}

\subsection{Estimation Results}

To find out the impact of independent variables on dependent variable, the techniques of Ordinary Least Square (OLS) has been adopted for obtaining the estimated results. The impact of various variables on inflation has been analyzed. Econometric model was used to check the significant impact of selected macroeconomic variables on Inflation (Consumer Price Index). The estimation results of the models are explained as follows.

\subsection{Estimation Results of Econometric Model}

The first regression equation is constructed in the logarithmic form as:

$$
\ell C P I=\beta o+\beta 1 \ell M S+\beta 2 \ell G E+\beta 3 \ell G R+\beta 4 \ell I N+\beta 5 \ell F D I+\beta 6 \ell G D P+\mu i
$$

where,

$$
\begin{aligned}
& \ell C P I=\text { Log of Consumer Price Index (Index } 2005=100) . \\
& \ell M S=\text { Log of Money Supply. } \\
& \ell G E=\text { Log of Government Expenditures. } \\
& \ell G R=\text { Log of Government Revenue. } \\
& \ell I N T=\text { Log of Interest Rate. } \\
& \ell F D I=\text { Log of Foreign Direct Investment. } \\
& \ell G D P=\text { Log of Gross Domestic Product. } \\
& \beta O=\text { Intercept. } \\
& \beta \text { 's }=\text { Slope Coefficients. } \\
& \mu i=\text { Error Term. }
\end{aligned}
$$

\subsection{Descriptive Statistics}

Descriptive statistics summarizes the mean (average), median, the minimum and maximum values, standard deviation, skewness and kurtosis of the data provided.

The table below represents descriptive statistics for the variables taken in the first model as Inflation ( $C P I)$, Money supply $(M S)$, Government Expenditure ( $G E)$, Government Revenue $(G R)$, Interest Rate $(I R)$, Foreign Direct Investment (FDI) and Gross Domestic Product (GDP).

In Table 1, the number of observations of each variable is 23 . The arithmetic mean (average) is the basic measure of central location that describes the middle of the data distribution with a single value. The mean values of Inflation (CPI), Money Supply ( $M S)$, Government Expenditure ( $G E)$, Government Revenue ( $G R$ ), Foreign Direct Investment (FDI), Interest Rate (INT) and Gross Domestic Product 
Table 1. Descriptive statistics model-1.

\begin{tabular}{cccccccc}
\hline & $C P I$ & $M S$ & $G E$ & $G R$ & $I N T$ & $F D I$ & $G D P$ \\
\hline Mean & 94.54552 & 2623.025 & 25.45785 & 945.7793 & 9.206087 & 84.46442 & 6103.841 \\
Median & 80.27897 & 1648.218 & 15.62608 & 619.069 & 9.83 & 30.93913 & 4209.873 \\
Maximum & 221.9137 & 8019.284 & 52.64494 & 2732.15 & 14.54 & 340.1276 & $20,653.87$ \\
Minimum & 32.26388 & 334.9913 & 9.36681 & 163.825 & 2.6 & 5.499447 & 855.943 \\
St. Deviation & 53.19158 & 2255.039 & 13.89193 & 795.3746 & 3.811629 & 104.3033 & 5647.261 \\
Skewness & 1.031084 & 0.978003 & 0.293499 & 1.033827 & -0.2982 & 1.471783 & 1.276031 \\
Kurtosis & 3.12738 & 2.811061 & 1.518045 & 2.756304 & 1.945712 & 3.915216 & 3.597416 \\
Jarque-Bera & 4.090899 & 3.700752 & 2.434893 & 4.153974 & 1.406076 & 9.106273 & 6.583676 \\
Probability & 0.129322 & 0.157178 & 0.295985 & 0.125307 & 0.495079 & 0.010534 & 0.037185 \\
Sum & 2174.547 & $60,329.57$ & 585.5306 & $21,752.92$ & 211.74 & 1942.682 & $140,388.3$ \\
Sum Sq. Dev & $62,245.56$ & $112,000,000$ & 4245.686 & $13,917,656$ & 319.6273 & 239,342 & $702,000,000$ \\
Observations & 23 & 23 & 23 & 23 & 23 & 23 & 23 \\
\hline
\end{tabular}

$(G D P)$ are $94.54552,2623.025,25.45785,945.7793,9.206087,84.46442$ and 6103.841 respectively. The minimum values of Inflation (CPI), Money Supply (MS), Government Expenditure $(G E)$, Government Revenue $(G R)$, Foreign Direct Investment $(F D I)$, Interest Rate (INT) and Gross Domestic Product (GDP) are 32.26388, 334.9913, $9.366810,163.8250,2.600000,5.499447$ and 855.9430 , whereas, the maximum values of all the selected variables are 221.9137, 8019.284, 52.64494, 2732.150, 14.54000, 340.1276 and 20,653.87.

Standard deviation (S.D) is the most important measure used for dispersement or scatterness of a data set in statistical theory. Simply, it shows how much of the data of the series is spread out around the arithmetic mean (average). When the standard deviation is large, it indicates that the data points are tightly close towards the mean, whereas a small standard deviation indicates that the data lies far away from the mean. The values of standard deviation of Inflation (CPI), Money Supply (MS), Government Expenditure $(G E)$, Government Revenue (GR), Foreign Direct Investment (FDI), Interest Rate (INT) and Gross Domestic Product $(G D P)$ are $53.19158,2255.039,13.89193,795.3746,3.811629,104.3033$ and 5647.26 .

Comparing the values of standard deviation of all the seven variables indicates that Money Supply (MS), Government Revenue $(G R)$ and Gross Domestic Product $(G D P)$ are relatively more volatile than Inflation $(C P D)$, Government Expenditure $(G E)$, Foreign Direct Investment $(F D I)$ and Interest Rate (INT).

Skewness is a parameter that indicates asymmetry in the probability distribution of a random variable. Table 1 shows that none of the variables is perfectly symmetrical (skewness $=0$ ). With a skewness of -0.298197 , the data for Interest Rate (INT) is approximately symmetric (range lies $\mathrm{b} / \mathrm{w}-0.5$ and +0.5 ). The distribution of $F D I(1.471783)$ and $G D P(1.276031)$ is highly skewed right (greater than +1$)$ whereas the skewness of $C P I(1.031084), M S(0.978003), G E(0.293499)$ 
and $G R(1.033827)$ indicates that they are moderately skewed right $(+1 / 2$ and $+1)$. Kurtosis indicates a sign of peakedness or flatness of a distribution used in data analysis. Table 1 confirms that none of the distribution of the variables is mesokurtic (kurtosis value $=3$ ). The distribution of CPI (3.127380), FDI (3.915216) and $G D P(3.597416)$ is leptokurtic (Kurtosis > 3) while that of MS (2.811061), $G E$ (1.518045), GR (2.756304) and INT (1.945712) is platykurtic (Kurtosis < 3). Jarque-Bera implicates the normality of a distribution. The insignificant coefficient (i.e. >0.05) of Jarque-Bera statistics for each series indicates that the frequency distributions of each series are normal.

\subsection{Stationarity Test}

In this study, unit root test is performed by using the Augmented Dickey-Fuller Test $(A D F)$. The procedure is to determine whether the data is stationary or not, by comparing the absolute value of the ADF statistic to the critical value in Tables 2 (a)-(b) at various confidence levels, $1 \%, 5 \%$ and $10 \%$. If the absolute value of the ADF statistic is greater than the critical value, then the observed data show stationary result. In contrast, if the absolute value of the ADF statistic is less than the critical value then the data is not stationary.

By comparison of the $A D F$ test statistic values with $1 \%, 5 \%$ and $10 \%$ critical values and their corresponding p-values, the result suggests that all the variables except $\ell$ MS in the table are found to be non-stationary in their levels whereas they become stationary after taking their 1st difference and thus the variables are said to be integrated of I (1). $\ell$ MS having a greater $A D F$ value and $\mathrm{p}$-value of 0.0065 at level proves that only it is stationary at level and the remaining variables confirm a unit root problem or they are non-stationary at level. To overcome this problem, these variables are tested at 1st difference after which they become stationary at $5 \%$ and $10 \%$ level.

\subsection{Regression Analysis}

The regression model analyzes the co-efficient, t-statistics and probability values of the variables taken under consideration. It also examines the value of $\mathrm{R}$-square, adjusted R-square, Durbin Watson statistics and F-statistics. The table below indicates the empirical results of regression applied on the first model with inflation $(C P I)$ as dependent variable (Table 3).

\subsection{Regression Equation}

The multiple regression equation of this analysis is represented as:

$$
\begin{aligned}
\ell C P I *= & -1.264+0.410 \ell M S+0.036 \ell G E *+0.066 \ell G R^{*} \\
& -0.501 \ell I N T^{*}+0.044 \ell F D I *+2.577 \ell G D P^{*}
\end{aligned}
$$

Results from the regression equation reveals that the coefficient of $\ell M S$ is 0.410 with a t-statistic value 6.871 and significant prob value of t-statistics indicating that with a 1 unit rise in money supply, inflation $(C P I)$ tends to increase by $41 \%$ This can be justified that in Pakistan, money supply has a direct relationship with price level and it is also confirmed from the classical macroeconomic 
Table 2. (a) Unit root estimation by augmented dickey fuller test (At level); (b) Unit root estimation by augmented dickey fuller test (At first difference).

(a)

\begin{tabular}{cccccc}
\hline Variables & t-stat & \multicolumn{3}{c}{ Critical levels } & p-value \\
\hline$\ell C P I$ & -0.669 & -3.788 & -3.012 & -2.646 & 0.834 \\
$\ell M S$ & -3.967 & -3.769 & -3.005 & -2.642 & 0.007 \\
$\ell G E$ & -1.758 & -3.769 & -3.005 & -2.642 & 0.39 \\
$\ell G R$ & -0.243 & -3.769 & -3.005 & -2.642 & 0.919 \\
$\ell F D I$ & -1.605 & -3.769 & -3.005 & -2.642 & 0.463 \\
$\ell I N T$ & -1.727 & -3.788 & -3.012 & -2.646 & 0.404 \\
\hline
\end{tabular}

(b)

\begin{tabular}{|c|c|c|c|c|c|}
\hline \multirow[t]{2}{*}{ Variables } & \multirow[t]{2}{*}{ t-stat } & \multicolumn{3}{|c|}{ Critical levels } & \multirow[t]{2}{*}{$\mathrm{p}$-value } \\
\hline & & 0.01 & 0.05 & 0.1 & \\
\hline$\ell C P I$ & -7.642 & -3.788 & -3.01 & -2.646 & 0 \\
\hline \multicolumn{6}{|l|}{$\ell M S$} \\
\hline$\ell G E$ & -3.3 & -3.788 & -3.01 & -2.646 & 0.028 \\
\hline$\ell G R$ & -5.259 & -3.788 & -3.01 & -2.646 & 0 \\
\hline$\ell F D I$ & -3.329 & -3.788 & -3.01 & -2.646 & 0.026 \\
\hline eINT & -3.032 & -3.788 & -3.01 & -2.646 & 0.048 \\
\hline
\end{tabular}

Table 3. Regression results model-1.

Dependent Variable: $\ell C P F^{\star}$

Method: Least Squares

Sample (Adjusted): 1991-2012

Included Observations: 22 after Adjustments

\begin{tabular}{cccc}
\hline Variable & Coefficient & t-Statistic & Prob. \\
\hline $\mathrm{C}$ & -1.26437 & -6.84186 & 0 \\
$\ell M S$ & 0.410339 & 6.8707 & 0 \\
$\ell G E^{*}$ & 0.035864 & 0.282974 & 0.7811 \\
$\ell G R^{*}$ & 0.066412 & 0.082171 & 0.9356 \\
$\ell I N T^{*}$ & -0.50052 & -5.33164 & 0.0001 \\
$\ell F D I^{*}$ & 0.044069 & 0.350524 & 0.7308 \\
$\ell G D P^{\star}$ & 2.577377 & 2.70284 & 0.0164 \\
R-square & 0.809447 & F-statistic & 10.61971 \\
Adjusted R-square & 0.733226 & Prob (F-statistic) & 0.000111 \\
Durbin Watson stat & 1.967033 & & \\
\hline
\end{tabular}

*: indicates variable is stationary at first difference. 
theory that a rise in money supply will lead to a rise in general price level in the economy. Broadly speaking, money supply has a positive effect on the general price level but through the demand side, although, a high level of money supply in the country will lead to a rise in investment level, promoting greater level of employment causing aggregate demand to rise and ultimately, inflation (CPI) will soar up in the economy. The findings of this study are in line with Liu \& Adedeji [23], Laryea, S. A. [24], Mehrnoosh, M. [25], Lim [7], Mukhtar [14], Abdullah [12], Kuijs [15], who found that there is a positive relationship between money supply and inflation in the long run.

$\ell G E$ having a coefficient value of 0.036 and a $\mathrm{t}$-statistic value of 0.283 implies that in Pakistan, a rise in government expenditure by $1 \%$ will lead to a $3.6 \%$ increase in inflation $(C P I)$. Although, it is not significant but having a positive coefficient value indicates that it has a direct relation with inflation. This can further be justified that if government expenditure is financed through printing of money, it will lead to inflation but on the other side if government expenditure is financed through borrowing then this will result in decreasing the level of inflation. In Pakistan, the government expenditure is financed through printing of money which raises the money supply resulting further increase in inflation. The effect of government expenditure on inflation is also from demand side in a country because with the increase in spending by the government there will be an upward pressure on the aggregate demand of goods and services and thus the overall level of prices will rise rapidly. This is consistent with the analysis of $\mathrm{Oz}$ len [16].

Our findings reveal that government revenue has a significant and positive impact on inflation $(C P I) . \ell G R$ having a coefficient value 0.066 with a significant t-statistic value 0.082 shows that as income from revenue rises by $1 \% C P I$ increases by $6.6 \%$. This is up to some extent in line with economic theory because increase in government revenue $(G R)$ has dual effect on inflation $(C P I)$. It can have both positive and negative impact on inflation. This may be interpreted as first an increase in government revenue will raise the price level but as the revenues goes into the hands of government, they will have to spend it on public welfare in the form of subsidies, rise in incomes or through different channels which will lead to reduction in price level. This simply means that government revenue has a positive relationship with inflation through increase in taxation and when again the money collected through taxes is spent on public, it may have negative impact on inflation.

Interest rate in Pakistan is implying negative impact on inflation, because $\ell$ INT having a negative coefficient value of -0.501 along with a significant $t$-statistic value -5.332 indicates that as rate of interest increases by $1 \%$, CPI reduces by 50 percent. Generally, a fall in rate of interest will encourage borrowing by the people which will increase spending by consumers and thus the economy will expand due to a rise in level of inflation. On the contrary, a rise in interest rate will discourage borrowing by the people as they will be holding a small amount of money and spending by the consumers will decrease which will definitely hamper the econ- 
omy due to a fall in inflation.

$\ell F D I$ is having a coefficient value 0.044 with a t-statistic value 0.351 , although this variable is not significant, implies that a $1 \%$ rise in foreign direct investment in Pakistan will lead to $4.4 \%$ increase in inflation. Foreign direct investment is attracted when domestic inflation is high. This clearly indicates a positive relationship between both variables. When foreign investors arrive in domestic market, the prices increase through greater demand for domestic raw and semi-finished goods, but when production through foreign direct investment increases, it ultimately leads to a fall in prices through an increase in supply of goods. FDI may also affect prices of certain goods but its overall impact on general price level or inflation maybe neutral (net effect $=0$ ).

$\ell G D P$ in the above equation is having a coefficient value 2.577 with a t-statistic value 2.703 indicating that an increase in gross domestic product by $1 \%$ will raise inflation by $2.6 \%$. GDP is a significant contributor to inflation. The reason behind the positive relationship between gross domestic product and inflation is that a rise in income level in Pakistan generates aggregate demand of certain commodities which brings about a rise in the general price level. Thus we can say that gross domestic product has an effect on inflation from demand side in Pakistan. The study is consistent with Mukhtar [14], and Abdullah [12].

The above result implies that the model is accurate and best fitted. The interpretation of the regression model in Table 3 is explained as under.

R-square tends to overestimate the strength of the association and shows how close the data is to the fitted regression line. Its value lies between 0 and 1 . Adjusted $R^{2}$ uses the R-square statistic and adjusts it on the basis of the residual degrees of freedom. By adding more explanatory variables, it will be smaller than $R^{2}$. Table 3 shows the value of R-square i.e. 0.809447 which implies that $81 \%$ of the variations in Inflation ( $C P I)$ is just explained by Money supply (MS), Government Expenditure $(G E)$, Government Revenue $(G R)$, Interest Rate $(I R)$, Foreign Direct Investment (FDI) and Gross Domestic Product (GDP). Moreover, the value of adjusted $R^{2}$ in the table is 0.733226 or $73.3 \%$ which shows the model is $73.3 \%$ best fitted.

Durbin-Watson test is carried out to test autocorrelation in the model. As the value of Durbin Watson statistic is 1.96 , which lies in the given range of 1.7 to 2.3 , justifying that no auto-correlation exists in the model and it can be used for further analysis.

Moreover, the F-statistics prob value of 0.000111 suggests the overall significance of the model and confirms that the model is jointly significant, proving that all the explanatory variables have a significant joint impact over the dependent variable, inflation $(C P I)$. The $\mathrm{t}$-value finds out the individual significance of a variable. If the probability value of $t$-statistics is less than 0.05 , then a variable is individually significant. Table 3 confirms that out of six explanatory variables, three of them are individually statistically significant which shows that there is no multicollinearity among the explanatory variables. 
The co-efficient of each independent variable shows the relationship with the dependent variable. In the table, $\log$ of $M S, G E, G R, F D I$ and $G D P$ have a positive coefficient while Log of Interest rate (INT) has a negative coefficient. The value of intercept is negative.

\subsection{Diagnostic Checks}

Several diagnostic tests are examined for checking validity of the model. They are explained as follows:

\subsubsection{Histogram-Normality Test}

Normality test is performed to examine the residuals in the data, whether it approaches a normal distribution or not. The Jarque-Bera test is used for this reason. If the p-value is more than $5 \%$, then Ho is rejected, which means that the model used passes the normality test. Normality test results for inflation is described in the following Table 4.

The table below shows the presence of normality of the data because the p-value of Jarque-Bera test statistic is larger than $5 \%$.

\subsubsection{Heteroscedasticity Test}

Heteroscedasticity is a condition when confounding factors (error) is not constant and the correlation between the explanatory variables and confounding factors occur as a result of imbalance data or the data are too varied. Tests were carried out to detect whether the observed data have heteroscedasticity or not, by using Breush-Pagan-Godfrey Test. If the probability value of $\mathrm{Obs}^{*} \mathrm{R}-\mathrm{Squared}$ is smaller than the significance level, it means that the presence of heteroscedasticity exists in the model. Meanwhile, if the p-value of $\mathrm{Obs}^{\star} \mathrm{R}$ Squared is greater than significance level, and then there is no heteroscedasticity in the model. Significance level used was $5 \%$. Heteroscedasticity test results of the first model are shown in Table 5 below.

From the test results in Table 5, it can be seen that for regression equation 1, there is no heteroscedasticity problem. It is shown from the corresponding probability value of $\mathrm{Obs}^{\star} \mathrm{R}$-Squared which is greater than the significance level of $5 \%$ used. Hence the result indicates homoscedastic variance in the model.

\subsubsection{Autocorrelation Test}

Autocorrelation occurs in a series of time series data, where the error term in one period of time depending on the systematic error term periods of time to another. The test is used to detect whether the observed data has autocorrelation or not. Here Serial Correlation LM Breusch-Godfrey Serial Test is used. The condition for this test is that if the probability value of $\mathrm{Obs}^{\star} \mathrm{R}$-Squared is smaller than the significance level, then autocorrelation will be found in the models, whereas, greater probability value of $\mathrm{Obs}^{\star} \mathrm{R}$-Squared indicates no presence of autocorrelation in the model. Significance level used here is 5\%. Autocorrelation test results for the equation can be seen in Table 6 . 
Table 4. Histogram normality test model-1.

\begin{tabular}{cc}
\hline Series: & Residuals \\
Sample & 19912012 \\
Observations & 22 \\
Mean & $-1.28 \mathrm{e}-16$ \\
Median & -0.023408 \\
Maximum & 0.144915 \\
Minimum & -0.127247 \\
Std. Dev. & 0.081521 \\
Skewness & 0.353082 \\
Kurtosis & 1.82463 \\
Jarque-Bera & 1.723483 \\
Probability & 0.422426 \\
\hline
\end{tabular}

Table 5. Heteroscedasticity test model-1 (Breusch-Pagan-Godfrey).

\begin{tabular}{cccc}
\hline F-statistic & 1.10317 & Prob. F(6,15) & 0.4052 \\
Obs ${ }^{\star}$ R-squared & 6.735665 & Prob. Chi-Square(6) & 0.346 \\
Scaled explained SS & 1.291061 & Prob. Chi-Square(6) & 0.9721 \\
\hline
\end{tabular}

Table 6. Serial correlation $1 \mathrm{M}$ test model-1.

\begin{tabular}{cccc}
\hline F-statistic & 0.163084 & Prob. F(2,13) & 0.8512 \\
Obs*R-squared & 0.538466 & Prob. Chi-Square(2) & 0.764 \\
\hline
\end{tabular}

The table above shows that the $\mathrm{p}$-value of $\mathrm{Obs}^{\star} \mathrm{R}$-Squared is greater than the significance level $5 \%$, hence implying no presence of autocorrelation in the model.

\section{Conclusions}

Inflation is one of the most crucial problems in developing countries especially in Pakistan, therefore different studies have been performed in several time periods on this issue. This research attempts to analyze the impact of different macroeconomic variables on inflation by employing time series data in Pakistan for a period of twenty three years from 1990 to 2012.

Inflation can effuse varied effects on an economy whether positive or negative creating uncertainty and far reaching social and economic consequences in the economy. The analysis from this study provides sufficient evidence that there are a large number of variables that determine the movement in the level of inflation. The results of the Augmented Dickey Fuller test illustrate that inflation, money supply, balance of trade and exchange rate are stationary at level, while consumer price index, government expenditure, government revenue, interest rate, for- 
eign direct investment, gross domestic product and trade openness are stationary at first difference.

To explore the impact of various macroeconomic variables on inflation in $\mathrm{Pa}$ kistan, the technique of regression has been carried out. In this regard, Consumer Price Index $(C P I)$ has been selected as a dependent variable and is used as a proxy for Inflation, whereas, the independent or explanatory variables used in this study are Money Supply (MS), Government Expenditure (GE), Government Revenue (GR), Interest Rate (INT), Foreign Direct Investment (FDI), Gross Domestic Product (GDP), Balance of Trade, Exchange Rate (EXR) and Trade Openness (TOP).

Using multiple regression analysis, this study found that money supply (MS), interest rate (INT) and gross domestic product $(G D P)$ significantly affect inflation in Pakistan. The study establishes a positive relation of inflation (INF) with money supply $(M S)$, government expenditure $(G E)$, government revenue $(G R)$, foreign direct investment $(F D I)$ and gross domestic product (GDP), while a negative relation is observed with interest rate (INT). Similarly, by using another regression model, we observe that inflation (INF) and Exchange rate $(E X R)$ have a negative and significant effect on balance of trade (BOT) while trade openness (TOP) has a positive effect on balance of trade in Pakistan from 1990-2012.

Correlation Analysis has been employed to find out the direction of relationship between inflation and macroeconomic variables. In this regard, inflation (INF) is selected as dependent variable and Money Supply (MS), Government Expenditure $(G E)$, Government Revenue $(G R)$, Interest Rate (INT), Foreign Direct Investment (FDI), Gross Domestic Product (GDP), Balance of Trade (BOT), Exchange Rate $(E X R)$ and Trade Openness (TOP) are taken as independent variables. Thus, on the basis of statistical examination of correlation matrix, it is concluded that there exists a positive association of inflation with money supply, government revenue, interest rate, foreign direct investment, gross domestic product, exchange rate and trade openness. The study also examines that inflation is negatively and weakly correlated with government expenditure but it has a strong negative association with Balance of Trade in Pakistan.

Finally, for investigating the causal relation between inflation and the selected variables, granger causality test is employed and the results from the test reveals that, there is a one way causation between money supply $(M S)$ and inflation (INF), balance of trade $(B O T)$ and inflation (INF), inflation $(I N F)$ and gross domestic product ( $G D P$ ); government expenditure $(G E)$ and money supply $(M S)$; inflation $(I N F)$ and government revenue $(G R)$; balance of trade $(B O T)$ and exchange rate $(E X R)$. Furthermore, bi-directional granger causality exists between gross domestic product $(G D P)$ and money supply $(M S)$, balance of trade and government revenue $(G R)$. The result of the study implies that all the empirical results are according to the formulated hypothesis.

\section{References}

[1] Pakistan Economic Survey (2011-2012) http://www.finance.gov.pk/ 
[2] Jhingan, M.L. (2002) Macro Economics Theory. Vrinda Publishers, New Delhi.

[3] Dwivedi, D.N. (2010) Macroeconomics Theory and Policy. 3rd Edition, Tata McGraw Hill Education, New Delhi, 453-456.

[4] Khan, A.A., Bukhari, S.K.H. and Ahmad, Q.M. (2007) Determinants of Recent Inflation in Pakistan. MPRA Paper No. 16254, 1-16.

[5] Hasan, A.M., Khan, A.H., Pasha, H.A. and Rasheed, A. (1995) What Explains the Current High Rate of Inflation in Pakistan. The Pakistan Development Review, 34, 927-943.

[6] Qayyum, A. (2006) Money, Inflation, and Growth in Pakistan. The Pakistan Development Review, 45, 203-212.

[7] Lim, C.H. and Papi, L. (1997) An Econometric Analysis of the Determinants of Inflation in Turkey. Working Paper, International Monetary Fund No: WP/97/170.

[8] Alfaro, L. (2004) Inflation, Openness and Exchange-Rate Regimes: The Quest of Short Term Commitment. Journal of Development Economics, 77, 229-249. https://doi.org/10.1016/j.jdeveco.2004.02.006

[9] Saleem, N. (2008) Measuring Volatility of Inflation in Pakistan: The Lahore Journal of Economics, 13, 99.

[10] Shahadudheen, I. (2012) A Cointegration and Error Correction Approach to the Determinants of Inflation in India. International Journal of Economic Research, 3, 105-112.

[11] Akbari, A.H. and Wimai, R. (2006) Inflation Targeting in a Small Emerging Market Economy: The Case of Pakistan. SBP Research Bulletin, 2, 169-190.

[12] Abdullah, M. and Kalim, R. (2009) Determinants of Food Price Inflation in Pakistan. Paper Presented in the Conference of University of Management Sciences, 1-21.

[13] Khan, R.E.A. and Gill, A.R. (2010) Determinants of Inflation: A Case of Pakistan (1970-2007). Journal of Economics, 1, 45-51. https://doi.org/10.1080/09765239.2010.11884923

[14] Mukhtar, T. (2010) Does Trade Openness Reduce Inflation? Empirical Evidence from Pakistan. The Lahore Journal of Economics, 15, 35-50.

[15] Kuijs, L. (1998) Determinants of Inflation, Exchange Rate, and Output in Nigeria. Issues 98-160 of IMF Working Paper.

[16] Ozlen, Ş. and Ergun, U. (2012) Macroeconomic Factors and Stock Returns. International Journal of Academic Research in Business and Social Sciences, 2, 315-343.

[17] Bashir, M.F., Nawaz, M.S., Yasin, M.K., Khursheed, M.U., Khan, M.J. and Qureshi, M.M.J. (2011) Determinants of Inflation in Pakistan: An Econometric Analysis using Johansen Co-Integration Approach. Australian Journal of Business and Management Research, 1, 71-82.

[18] Solomon, M. and de Wet, W.A. (2004) The Effect of a Budget Deficit on Inflation: The Case of Tanzania. South African Journal of Economic and Management Sciences, 7, 100-116. https://doi.org/10.4102/sajems.v7i1.1431

[19] Pakistan Economic Survey (2007). http://www.finance.gov.pk/

[20] Zîna, C. (2014) Monetary Policy, Inflation and the Causal Relation between the Inflation Rate and Some of the Macroeconomic Variables. Procedia Economic and Finance, 16, 391-401. https://doi.org/10.1016/S2212-5671(14)00818-1

[21] Mosayeb, P. and Mohammad, R. (2009) Sources of Inflation in Iran: An Application of the Real Approach. International Journal of Applied Econometrics and Quantitative Studies, 6, 61-76. 
[22] Olatunji, G.B., Omotesho, O.A., Ayinde, O.E. and Ayindo, K. (2010) Determinants of Inflation in Nigeria: A Co-Integration Approach. Paper Presented at the Joint 3rd African Association of Agricultural Economists, 1-12.

[23] Liu and Adedeji (2000) Determinants of Inflation in the Islamic Republic of Iran. A Macroeconomic Analysis. IMF Working Papers, Middle Eastern Department.

[24] Laryea, S.A. and Sumaila, U.R. (2001) Determinants of Inflation in Tanzania. CMI Working Paper WP/97/145. IMF, Washington DC.

[25] Mehrnoosh, M. and Feizolah, J. (2016) Examining the Effects of Inflation and Unemployment on Economic Growth in Iran (1996-2012). Procedia Economic and Finance, 36, 381-389. https://doi.org/10.1016/S2212-5671(16)30050-8 